\title{
Micropropagation's Complete Protocol of Red Araçá (Psidium cattleianum, Myrtaceae) from Germinated Seeds in vitro
}

\author{
Cassio G. Freire ${ }^{1}$, João P. P. Gardin ${ }^{2}$, César M. Baratto ${ }^{2}$, Renato L. Vieira ${ }^{3} \&$ Simone S. Werner $^{4}$ \\ ${ }^{1}$ University Alto Vale do Rio do Peixe (UNIARP), Caçador, SC, Brazil \\ ${ }^{2}$ University of West of Santa Catarina (UNOESC), Videira, SC, Brazil \\ ${ }^{3}$ Agricultural Research and Rural Extension Company of Santa Catarina (EPAGRI), Experimental Station of \\ Caçador, SC, Brazil \\ ${ }^{4}$ Agricultural Research and Rural Extension Company of Santa Catarina (EPAGRI), Experimental Station of \\ Lages, SC, Brazil \\ Correspondence: Cassio G. Freire, University Alto Vale do Rio do Peixe (UNIARP), 800, St. Victor Baptista \\ Adami, Center, Caçador, Zip Code: 89500-199, Santa Catarina, Brazil. Tel: 55-49-99132-9590. E-mail: \\ cassio.geremia@uniarp.edu.br
}

Received: November 16, 2017

Accepted: December 20, 2017 Online Published: January 15, 2018

doi:10.5539/jas.v10n2p234

URL: https://doi.org/10.5539/jas.v10n2p234

The research is financed by UNIEDU Graduate Program of the State of Santa Catarina; Universidade Alto Vale do Rio do Peixe (UNIARP); Universidade do Oeste de Santa Catarina (UNOESC) and Agricultural Research and Rural Extension Company of Santa Catarina (EPAGRI).

\begin{abstract}
Red Araçá's (Psidium cattleianum) micropropagation processes have shown enormous potential both in terms of research and as a sustainable native resource to be used in the areas of food production, ecology, and pharmacology. Currently, however, despite that potential, research efforts involving this myrtaceae, native to the Brazilian Atlantic Forest, have been scarce. With that in mind, this study set out to establish micropropagation techniques that would allow the development of a feasible protocol to be used with Red Araçá, achieving its mircropropagation from in vitro germinated seeds. Different types of explants were tested for in vitro establishment. For the multiplication of nodal segments, different concentrations of BAP and IAA combinations were tested in an MS medium. Using the same medium, different concentrations of ampicillin were applied in order to determine its influence on the decontamination of the apical segments. The BAP and IAA combinations were also used to test their effects on the in vitro explants' development and rooting. During pre-acclimatization, survival of in vitro rooted plants was tested in a nebulizer chamber, using a commercial substrate and that same substrate mixed with washed sand (1:1). In essence, it was indeed possible to develop a complete protocol for the micropropagation of the Red Araçá from seedlings obtained by in vitro germination. The in vitro introduction of the Red Araçá was rather efficient, independently of the type of explants used. As the BAP and IAA concentrations increased, so did the in vitro seedlings' development (7 leaves explant $\left.{ }^{-1}\right)$ and rooting (67\%). Additionally, the in vitro rooted plants exhibited a high rate of survival $(80 \%)$ in the pre-acclimatization phase, independently of the substrate used.
\end{abstract}

Keywords: red strawberry guava, Araza, Atlantic Forest, benzylaminopurine, in vitro explants, apical segments

\section{Introduction}

Red Araçá (Psidium cattleianum Sabine) is a species native to the Mata Atlântica (Atlantic Forest), a Brazilian ecosystem hotspot (RBMA, 2017; Myers et al., 2000), and can be found throughout the Brazilian territory (Vibrans, 2013), as well as in other ecosystems in the world (Tng et al., 2015).

Akin to other myrtaceae, the Red Araçá's research potential is of great importance to the food production, ecology, and pharmacology fields of study (Raseira, Antunes, Trevisan, \& Gonçalves, 2004; Franzon, Campos, Proença, \& Sousa-Silva, 2009; Kinupp, 2011). Because its fruit is juicy and contains large quantities of nutrients (Galho et al., 2007), the food industry can process it or use it in natura. Also, its leaves and fruit contain different 
bioactive compounds (Silva, Rodrigues, Mercadante, \& De Rosso, 2014), essential oils and volatile substances that play an important role in pharmacology (Marin et al., 2008). Additionally, its capacity to attract pollinators (Gressler, Pizo, \& Morelatto, 2006) and produce food for the native fauna (H. G. Baker, I. Baker, \& Hodges, 1998; Kuhlmann, 1975) makes it an attractive species to be used as a secondary tree in reforestation efforts of degraded areas (Embrapa, 2006).

The array of potential exhibited by the Red Araçá has drawn the attention of the Brazilian Ministry of the Environment, which included it in their list of food producing native species with immediate or future potential uses in tropical and subtropical ecosystems (Kinupp, 2011). It has also been identified as an important species in the apiculture industry (Falkenberg \& Simões, 2011). In spite of its importance and potential in the above mentioned fields, research efforts involving the biological diversity, conservation, and in vitro propagation of this species are rather scarce (Pasqual, Chagas, Soares, \& Rodrigues, 2012).

Germination is the classic propagation method for this species (Lorenzi, 2008; Raseira, Antunes, Trevisan, \& Gonçalves, 2004). However, its seeds' rocklike consistency (testa petrea) and integumental impermeability (Da Silva, Gualtieri, Paula, \& Paoli, 2013) makes the germination of the Red Araçá less homogeneous, reducing its physiological quality during storage (Cisneiro et al., 2003). This has led recent studies to concentrate on optimizing the in vitro production of the species through micropropagation processes (Ribeiro, Souza, Donini, \& Schuch, 2007), using material obtained from an adult plant or from in vitro germination (Freire, Gardin, Baratto, \& Vieira, 2017).

Research efforts involving the different micropropagation phases of the $P$. cattleianum are still rare in many aspects. Some studies involving in vitro introduction and multiplication have already been developed, and yielded evidence of problems with phenolic oxidation and high rates of microbial contamination (Freire, Oliveira, \& Vieira, 2014; Rodríguez, 2013).

Furthermore, complete protocols for the in vitro propagation of other species of the Psidium genus, such as the Red Guava (P. guajava) (Liu \& Yang, 2011), are already available and have been widely used in several fields in Brazil and around the world (IEA, 2017). All of this has made it quite clear that there is a need for further studies involving P. cattleianum micropropagation techniques, in order to better understand this genetic resource native to the Atlantic Forest. The purpose of this study, therefore, was to devise micropropagation techniques for the in vitro introduction, establishment, multiplication, rooting and pre-acclimatization of $P$. cattleianum, and develop a feasible protocol related to the specie.

\section{Materials and Methods}

This study used different experiments to test the establishment, multiplication, rooting and pre-acclimatization of Red Araçá from seedlings obtained by in vitro germination (see Figure 1).

\subsection{General Conditions for the Experiments}

The germination, establishment, multiplication and rooting experiments with Red Araçá were all performed at the Plant Tissue Cultures Laboratory belonging to the Experimental Station of the Agricultural Research and Rural Extension Company from Santa Catarina (Epagri), in the City of Caçador. There, the experiments were assembled in a plant growth chamber, set at a temperature of $25 \pm 2{ }^{\circ} \mathrm{C}$, where glass flasks ( $230 \mathrm{~mL}$ capacity) or test tubes $(25 \times 150 \mathrm{~mm})$ were exposed to a 16-hour photoperiod, with a luminous intensity of $75 \mu \mathrm{mol} \mathrm{m} \mathrm{m}^{-2} \mathrm{~s}^{-1}$, obtained using cool white fluorescent bulbs.

An MS medium was used (Murashige \& Skoog, 1962), with all its mineral salts and vitamins, and supplemented by $30 \mathrm{~g} \mathrm{~L}^{-1}$ of sucrose and phytohormones, both dependent on each experiment. The $\mathrm{pH}$ factor was always adjusted to $5.8 \pm 0.05$ before adding the solidifying agent $\left[6 \mathrm{~g} \mathrm{~L}^{-1}\right.$ of agar $($ Merck $\left.®)\right]$.

Different assessments of the explants' characteristics were performed after each experiment. Bacterial and filamentous fungal contaminations were quantified according to Scherwinski-Pereira (2010). Partially or totally darkened explants were considered oxidized, whereas the explants that were greenish in color or totally green, and had developed at least one bud or leaf were considered to be established. Rooting was assessed by visually analyzing the growth of adventitious roots, according to Grattapaglia and Machado (1998). The number of completely formed and expanded leaves were counted. The growth of the in vitro explants was assessed using the relative growth rate (RGR) established by Briggs, Kid, and West (1920), according to Equation 1:

$$
T C R=[(\operatorname{LnC} 2-\operatorname{LnC1}) /(t 2-t 1)]
$$

where, $L n$ is the natural or Naperian logarithm for the length values obtained from the different assessments; and $C 2$ and $C 1$ represent the growth (in $\mathrm{mm}$ ) recorded at the specific times $t 2$ (final) and $t 1$ (initial). 
Results were assessed by a 'standard statistical test' using analyses of variance (ANOVA) and accordingly verifying normality and homoscedasticity prerequisites based on the Shapiro-Wilk Normality Test and Bartlett's Test. Subsequently, the means were separated using the Tukey or Scott-Knott Tests $(p<0.05)$ for the qualitative variables and a study of regression for quantitative variables $(\mathrm{p}<0.05)$. Software applications used included Microsoft Excel ${ }^{\circledR}$ 2013, R ${ }^{\circledR}$ v. 3.2.3, Assistat ${ }^{\circledR} 7.7$ beta (Silva \& Azevedo, 2009) and GraphPad Prism ${ }^{\circledR}$ v. 5.00. Different data analyses and data transformations are described within each experiment, when appropriate.

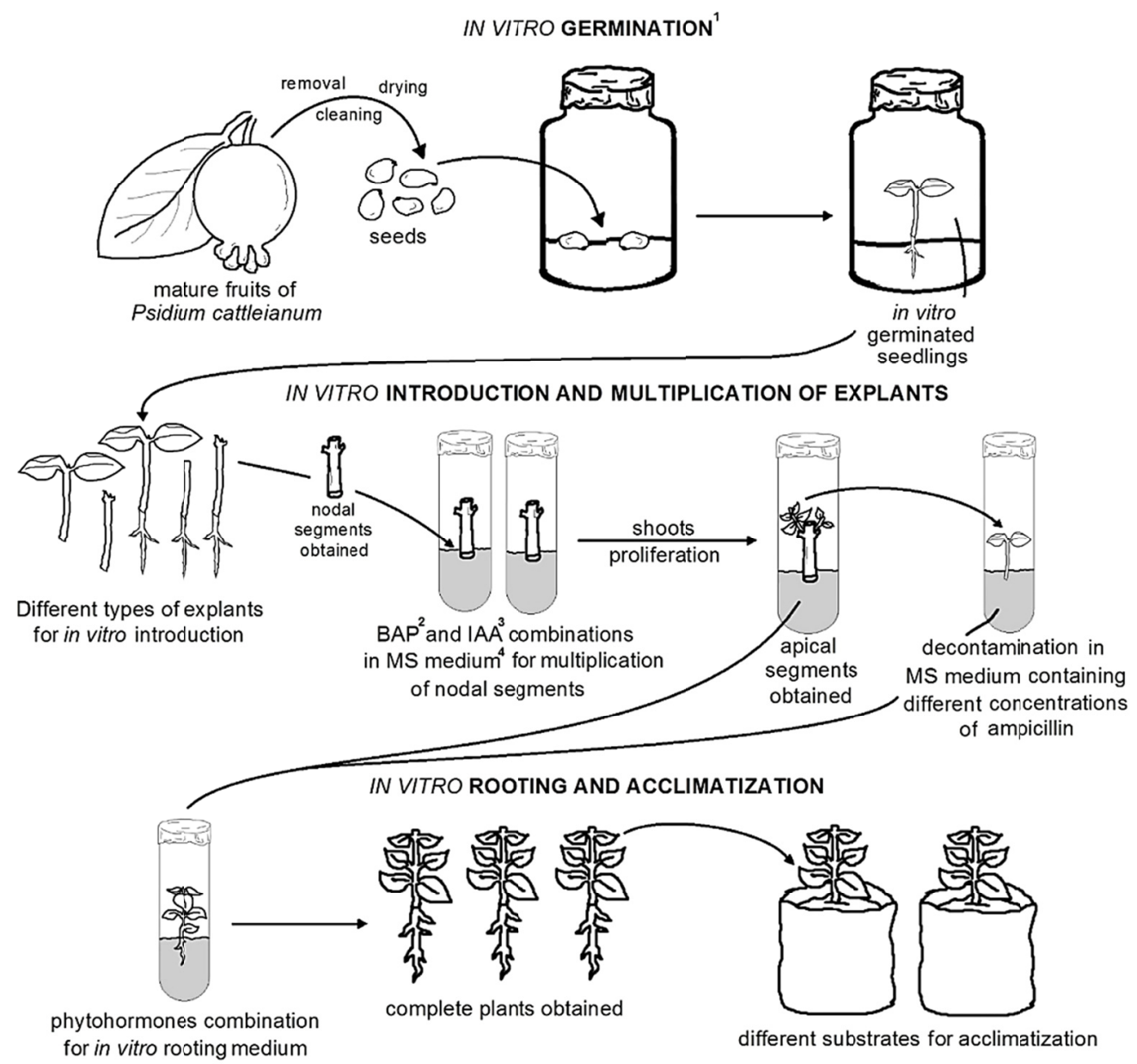

Figure 1. Flow diagram showing the different phases and experiments performed in order to develop an in vitro propagation protocol for the Red Araçá (Psidium cattleianum)

Note. ${ }^{1}$ Accordint to Freire, Gardin, Baratto, and Vieira (2017). ${ }^{2}$ Benzylaminopurine. ${ }^{3}$ Indoleacetic acid. ${ }^{4} \mathrm{MS}$ Medium (Murashige \& Skoog, 1962).

\subsection{In Vitro Establishment of Red Araçá Seedlings}

The process used to obtain the in vitro germinated seedlings was performed according to Freire, Gardin, Baratto, and Vieira (2017), and the experiment design was completely randomized, with five repetitions of five explants each. The five different treatments shown in Figure 2 were studied. The explants were established in an MS medium, supplemented by $2.0 \mathrm{mg} \mathrm{L}^{-1}$ of Benzylaminopurine (BAP) and $2.0 \mathrm{~g} \mathrm{~L}^{-1}$ of powdered activated carbon. They were then kept in the dark for the first five days, and under plant growth chamber conditions for the rest of the experiment. The following variables were studied: bacterial and fungal contamination percentages, oxidation percentage and establishment percentage, all on the 30th day after introduction into the culture medium.

Responses for the bacterial contamination, fungal contamination and oxidation variables were almost all zero; the establishment variable was, therefore, the only variable that was verified with an analysis of variance (ANOVA). 


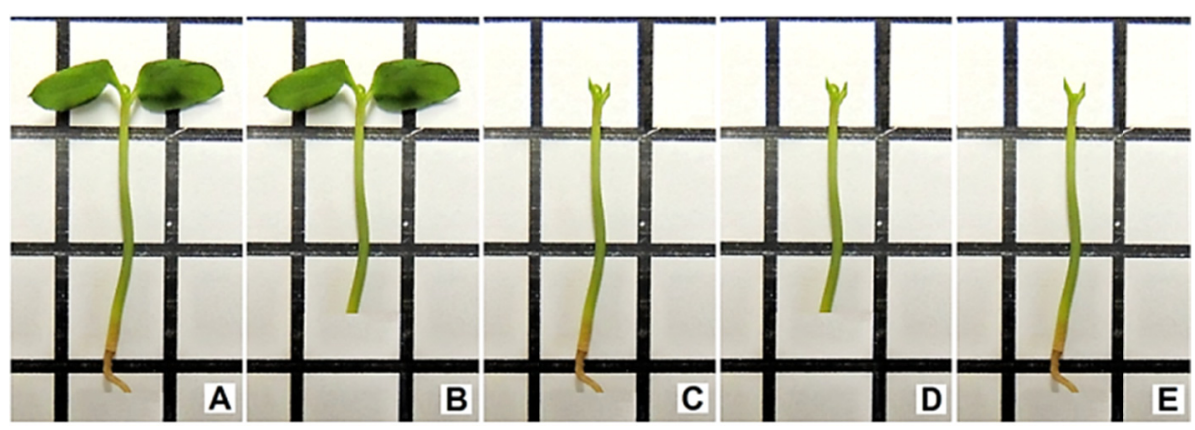

Figure 2. Types of explants in the micropropagation of Psidium cattleianum (Red Araçá) derived from in vitro germinated seedlings

Note. A, explants containing paracotyledons and 4-6 mm radicle roots; B, explants containing paracotyledons, without radicle roots; $\mathrm{C}$, explants containing apical follicles and 4-6 mm radicle roots; $\mathrm{D}$, explants containing only apical follicles, without radicle roots; and E, explants without apical buds, but with 4-6 mm radicle roots. Squares were dimensioned at $1 \mathrm{~cm}$ by $1 \mathrm{~cm}$. Epagri's Plant Tissue Cultures Laboratory in Caçador.

\subsection{Growth Phytohormones during the Morphogenesis of Nodal Shoot Segments}

After in vitro establishment, different concentrations of BAP and Indoleacetic Acid (IAA) were tested in the multiplication and rooting phases. The experiment design was completely randomized, with five explants per repetition, seven repetitions per treatment and five different treatments, totaling 175 explants. The BAP and IAA concentrations used for the treatments were mixed in a 3:1 proportion (in $\mathrm{mg} \mathrm{L}^{-1}$ ) as follows: 1 - BAP (0), IAA (0); 2 - BAP (0.3), IAA (0.1); 3 - BAP (0.6), IAA (0.2); 4 - BAP (0.9), IAA (0.3); and 5 - BAP (1.5), IAA (0.5). The above treatments were applied to the nodal segments with lengths of 7 to $9 \mathrm{~mm}$ and containing 2 lateral buds, which were introduced into test tubes containing $8 \mathrm{~mL}$ of MS medium, supplemented by $250 \mathrm{mg} \mathrm{L}^{-1}$ of polyvinylpyrrolidone (PVP Vetec ${ }^{\circledR}$ ) and $2 \mathrm{~g} \mathrm{~L}^{-1}$ of powdered activated carbon.

On the 15th and 45th days after the in vitro introduction, the bacterial contamination percentage, oxidation percentage and the number of buds per explant were assessed. Also assessed after the 45th day of in vitro introduction were the number of leaves per explant and the percentage of established explants.

\subsection{Different Concentrations of Antibiotics in the Culture Medium}

Some of the explants developed buds but, at the same time, showed bacterial contamination at its base. To avoid discarding these explants and also to find out if they could be decontaminated, a separate experiment was set up by adding antibiotics to the culture medium. Again, the experiment design was completely randomized, with two treatments (with ampicillin concentrations of $250 \mathrm{mg} \mathrm{L}^{-1}$ and $500 \mathrm{mg} \mathrm{L}^{-1}$ in the medium) comprised of 4 repetitions of 5 explants each. The MS medium used was supplemented by $1.5 \mathrm{mg} \mathrm{L}^{-1}$ of BAP, $0.5 \mathrm{mg} \mathrm{L}^{-1}$ of Naphthaleneacetic Acid (NAA), $0.5 \mathrm{~g} \mathrm{~L}^{-1}$ of powdered activated carbon, and $250 \mathrm{mg} \mathrm{L}^{-1}$ of PVP (Vetec $\left.\mathbb{R}\right)$. The ampicillin was added to the post-autoclaved medium inside a laminar air flow cabinet, using solutions that were sterilized by microfiltration (with a Millex ${ }^{\circledR}-\mathrm{HV} 0.45 \mu \mathrm{m}$ microfilter). Subsequently, $10 \mathrm{~mL}$ of the culture medium was poured into each test tube.

Apical segments between 6-11 $\mathrm{mm}$ in length, and contaminated with bacterial colonies of the same aspect (circular-punctiform) and characteristics (rosy coloration containing similar DNA coding for the 16S rRNA region) were individually introduced into test tubes.

Evaluations were performed on the 15th and 35th day after the explants were introduced into the medium. The response variables assessed were as follows: bacterial and fungal contamination percentages; oxidation percentage; rooting percentage; number of fully formed leaves produced; and relative growth rate (RGR in mm $\mathrm{mm}^{-1}$ day $\left.^{-1}\right)$.

\subsection{Growth Phytohormones during the Morphogenesis of Apical Segments}

Non-contaminated buds obtained through in vitro explant regeneration were submitted to three treatments, comprised of 5 repetitions, with 3 explants each, in a completely randomized design.

The MS medium used was supplemented by $0.5 \mathrm{~g} \mathrm{~L}^{-1}$ of powdered activated carbon, $250 \mathrm{mg} \mathrm{L}^{-1}$ of PVP (Vetec $($ ) and $125 \mathrm{mg} \mathrm{L}^{-1}$ of ampicillin (sterilized in a Millex ${ }^{\circledR}-\mathrm{HV} 0.45 \mu \mathrm{m}$ microfilter). The experiment used the following three different concentrations of phytohormones as its variables, which were added to the MS medium 
prior to autoclaving: T1, $1 \mathrm{mg} \mathrm{L}^{-1}$ of BAP; T2, $2 \mathrm{mg} \mathrm{L}^{-1}$ of BAP; and T3, $2 \mathrm{mg} \mathrm{L}^{-1}$ of BAP and $0.5 \mathrm{mg} \mathrm{L}^{-1}$ of IAA. The culture medium $(10 \mathrm{~mL})$ was mixed into each of the test tubes. Apical segments between $8-12 \mathrm{~mm}$ in length were individually introduced into recipients containing the medium.

The following variables were collected on the 18th and 40th days: bacterial and fungal percentages; oxidation percentage; rooting percentage; number of fully generated leaves; and relative growth rate (RGR, in $\mathrm{mm} \mathrm{mm}^{-1}$ day $\left.^{-1}\right)$.

\subsection{Pre-Acclimatization of Micropropagated Red Araçá Plants}

This experiment was performed at Epagri's Laboratory for Genetic Improvement of Temperate Climate Fruit Bearing Plants, in the City of Caçador.

In vitro multiplied and rooted Red Araçá plants were used, more specifically the ones that had between 8-10 fully formed leaves and a weighed average length of $17.40 \mathrm{~mm}$. The experiment design was completely randomized, with 11 repetitions of one plant each, per treatment. Two types of substrate were tested in the transplantation: S1, a commercial substrate from Maxfértil ${ }^{\circledR}$ (with pine bark, ashes, vermiculite, sawdust and biostabilizers; electrical conductivity of $0.50 \pm 0.30 \mathrm{mS} \mathrm{cm}^{-1} ; \mathrm{pH}_{\text {water }}$ of $6.00 \pm 0.5$ (at $25^{\circ} \mathrm{C}$ ); maximum humidity of $58.00 \%$; water retention capacity of $90.00 \%$; and density of $310 \mathrm{~kg} \mathrm{~m}^{-3}$ ); and $\mathrm{S} 2$, the same commercial substrate from Maxfértil ${ }^{\circledR}$ mixed with sterilized washed sand, in a 1:1 mass proportion.

The plants were washed with distilled water and transferred to $17 \times 17 \times 22 \mathrm{~cm}$ plastic bags, containing the above mentioned substrates, already moistened with $100 \mathrm{~mL}$ of mineral water. All plants were kept in a climate controlled incubator chamber with a nebulizer control system (relative humidity between $85 \%$ and $97 \%$ ), and a temperature of $25 \pm 1.0^{\circ} \mathrm{C}$ (see Figure 3).

On the 20th and 42nd days after transplantation, survival of the plants was assessed, with the ones that showed development, i.e. were soft, had a greenish coloration, and produced and maintained leaves, being considered as survivors. The data was analyzed using binomial distribution and the Chi-square test (5\% probability), taking the substrate and assessment date factors into consideration.

During the experiment, the plants were periodically irrigated (an average of $12 \mathrm{~mL} \mathrm{day}^{-1}$ ) and, ten days after the transplantation, $50 \mathrm{~mL}$ plant $^{-1}$ of MS medium was added (note that the medium had no sucrose or agar, and its $\mathrm{pH}$ was adjusted to $6.0 \pm 0.05$ ).

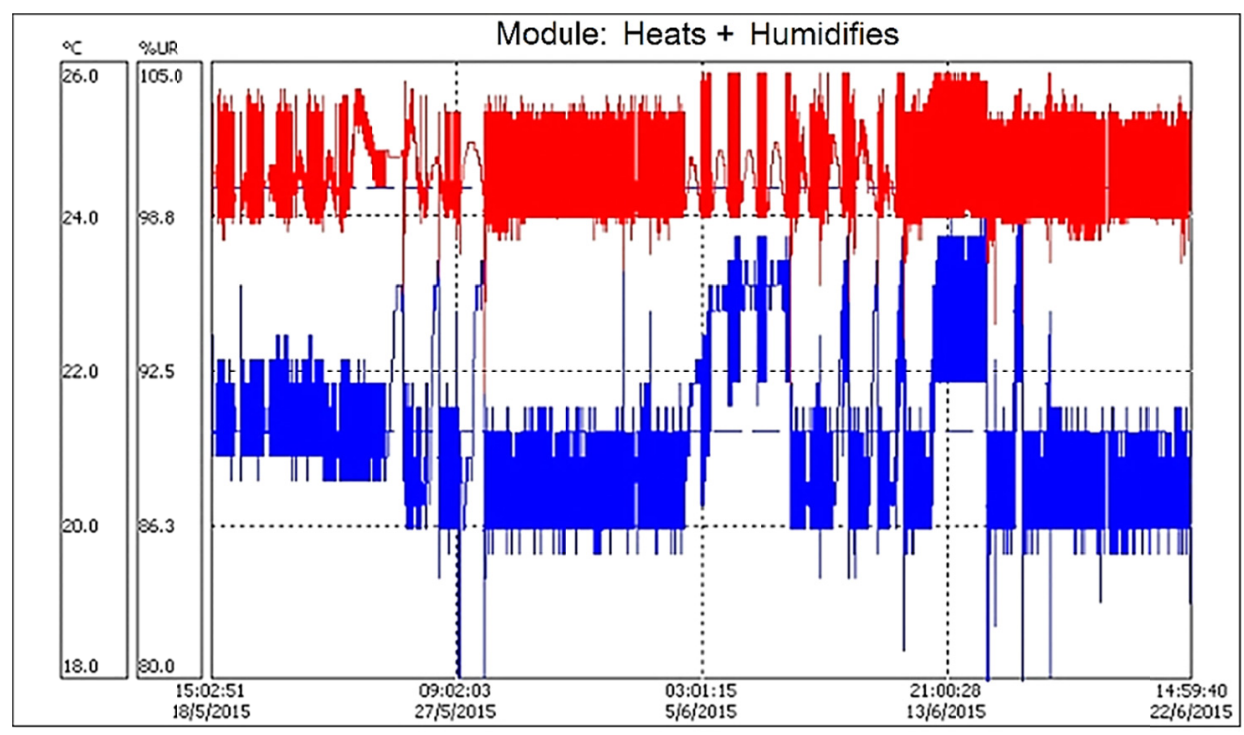

Figure 3. Nebulizer chamber's temperature and humidity conditions during the pre-acclimatization experiment using micropropagated Psidium cattleianum plants

Note. Epagri's Laboratory for Genetic Improvement of Temperate Climate Fruit Bearing Plants, in the City of Caçador. 


\section{Results and Discussion}

\subsection{In Vitro Establishment of Red Araçá Seedlings}

Table 1 shows results for bacterial and fungal percentages, oxidation percentages and establishment percentages. As can be seen, results didn't vary for the different types of explant $(p>0.05)$, but were efficient in establishing the species in vitro.

Table 1. Bacterial and fungal contamination percentages, oxidation percentages, and establishment percentages for Red Araçá explants, 30 days after in vitro introduction of seedlings obtained by germination

\begin{tabular}{|c|c|c|c|c|}
\hline Type of explant & Bact. $^{2}(\%)$ & Fung. $^{3}(\%)$ & Oxid. $^{4}(\%)$ & Estab. $^{5}(\%)$ \\
\hline (A) Containing paracotyledons and radicle ${ }^{1}$ & 0 & 0 & 8 & $92^{\text {ns }}$ \\
\hline (B) Containing paracotyledons, without radicle & 0 & 0 & 4 & 96 \\
\hline (C) Containing only apical follicles and radicle & 0 & 0 & 0 & 96 \\
\hline (D) Containing only apical follicles, without radicle & 8 & 0 & 0 & 92 \\
\hline (E) Without apical buds, but with radicle & 0 & 0 & 4 & 96 \\
\hline CV (\%) & - & - & - & 11.51 \\
\hline
\end{tabular}

Note. ${ }^{1}$ Radicle root between 4-6 mm; ${ }^{2}$ Bacterial contamination; ${ }^{3}$ Fungal contamination; ${ }^{4}$ Explant oxidation; ${ }^{5}$ In vitro explant establishment. ${ }^{\text {ns }}$ Not significant, based on the analysis of variance's $\mathrm{F}$ test.

Table 1 shows that only treatment $\mathrm{D}$ had bacterial contamination $(8 \%)$ and not one of the types of explant tested had fungal contamination. All types of explant also exhibited low percentages of oxidation, and an average of about $95 \%$ establishment.

Differences between the types of explant were expected, especially considering the variations in size, and the presence or absence of paracotyledons and radicle roots. Such factors can influence, for example, the quantity of nutritional reserves present in the explants, which could affect in vitro establishment (Hartmann, Kester, \& Davies Junior, 1990). Grattapaglia and Machado (1998) also determined that bigger explants with leaves have a better possibility of in vitro development. By the same token, Souza et al. (2007) used different sized explants $(0.5 \mathrm{~cm} ; 1.0 \mathrm{~cm} ; 1.5 \mathrm{~cm})$ during the in vitro introduction of the "pitangueira" plant (Eugenia uniflora, Myrtaceae), and determined that the bigger explants showed significantly higher results than their smaller counterparts, with approximately $83 \%$ having been established by the 45 th day of cultivation.

Previous studies had already tested different methods of in vitro introduction for the $P$. cattleianum, but the results were less than satisfactory. Freire, Oliveira, and Vieira (2014) tested different asepsis methods (with ethanol $70 \% \mathrm{v} / \mathrm{v}$ and sodium hypochlorite $1.5 \%$ ) on P. cattleianum explants obtained from stock plants that had gone through previous fungal treatment. These authors had problems with bacterial contamination (average of $50 \%$, with $95 \%$ for the control group) and fungal contamination (average of $13.34 \%$, with $55 \%$ for the control group). Similar data was observed by Souza, Schuch, and Silva (2006) who, when testing the introduction of $P$. cattleianum cv. "Irapuã" using semi-lignified and herbaceous shoots, found that the average percentage of bacterial and fungal contaminations were $89.68 \%$ and $46.85 \%$, respectively.

Furthermore, the in vitro establishment of native Myrtaceae trees, such as the Red Araçá, also poses problems due to oxidation processes that take place in explants obtained from stock plants (Pasqual, Chagas, Soares, \& Rodrigues, 2012). The high concentration of phenolic compounds in these species and the use of different disinfectants during the decontamination process increase oxidation and decrease in vitro survival rates (Grattapaglia \& Machado, 1998). In general, these negative factors impair or make the subsequent phases of micropropagation unfeasible for different myrtaceae, as has been determined for the "cerejeira-do-mato" (Eugenia involucrata or cherry of the Rio Grande) (Golle, Reiniger, Belle, \& Curti, 2013) and for the "pitangueira" (Eugenia uniflora) (Lattuada, 2010), for example.

Contrary to those efforts, in this study, the use of explants derived from in vitro germinated seedlings has proven a rather feasible technique to study the micropropagation capabilities of the Red Araçá. As a matter of fact, the percentages related to bacterial contamination and oxidation were virtually null, and no explant fungal contamination was detected after the 30th day of in vitro introduction (Table 1). Such data is of great importance, especially considering the fact that the Red Araçá is a myrtaceae tree with a high incidence of contamination and oxidation during in vitro introduction (George, Hall, \& De Klerk, 2008). 
When studying the micropropagation of Myrtaceae species, other authors have also used explants obtained from in vitro germinated seedlings. Souza (2010), for example, yielded high in vitro establishment and multiplication rates with "guabijuzeiro" (Myrcianthes pungens) explants obtained from in vitro germinated seeds. Similarly, Nascimento (2006) germinated "uvaieira" (Eugenia pyriformis) seeds and reported rather high establishment, multiplication, and rooting percentages for that species' explants.

\subsection{Growth Phytohormones during the Morphogenesis of Nodal Shoot Segments}

Table 2 shows results for Psidium cattleianum explants after 15 days in vitro.

Table 2. Bacterial contamination percentages, oxidation percentages, and number of buds per explant for Psidium cattleianum nodal segments cultivated in different concentrations of BAP and IAA, after 15 days in vitro

\begin{tabular}{lllll}
\hline BAP $\left(\mathrm{mg} \mathrm{L}^{-1}\right)$ & IAA $\left(\mathrm{mg} \mathrm{L}^{-1}\right)$ & Bacterial Contamination $(\%)$ & Buds explant $^{-1}$ & Oxidation $(\%)^{\text {ns }}$ \\
\hline 0 & 0 & $77.14 \mathrm{a}$ & $0.51^{\mathrm{ns}}$ & $22.86^{\mathrm{ns}}$ \\
0.3 & 0.1 & $97.14 \mathrm{a}$ & 0.31 & 17.14 \\
0.6 & 0.2 & $74.29 \mathrm{a}$ & 0.29 & 28.57 \\
0.9 & 0.3 & $85.71 \mathrm{a}$ & 0.14 & 34.29 \\
1.5 & 0.5 & $28.57 \mathrm{~b}$ & 0.57 & 20.00 \\
CV $(\%)$ & & 24.80 & 81.99 & 71.05 \\
\hline
\end{tabular}

Note. Averages appended by the same lower case letter within a column do not differ statistically from each other according to the Scott-Knott test, within a 5\% significance level. ${ }^{\text {ns }}$ Not significant.

The nodal segments used in this experiment were excised from in vitro introduced explants that remained over 90 days without visible contamination. Despite that, after the 12th day of the in vitro experiment, many of the segments (Table 2) showed bacterial contamination with the same appearance and coloration as was observed at the base of the explants, eventually developing towards the outside of the culture medium within the test tubes. Thus, a high bacterial contamination percentage $(\mathrm{p}<0.0001)$ was observed (see Table 2$)$, with the exception of the trial involving treatment $\mathrm{T} 5\left(1.5 \mathrm{mg} \mathrm{L}^{-1}\right.$ of BAP $+0.5 \mathrm{mg} \mathrm{L}^{-1}$ of IAA), which yielded a value $(28.57 \%)$ significantly lower than the rest.

Comparable to what was seen in this P. cattleianum study, other research efforts, such as the ones involving the in vitro establishment of "cerejeira-do-mato" (Eugenia involucrata) (Paim, 2011) and "camu-camuzeiro" (Myrciaria dubia) (Araújo, 2012), have detected the proliferation of bacterial contamination after a few weeks in vitro. According to these authors, such contaminations were very possibly due to the presence of endophytic microorganisms.

As stated by Camara, Willadino, and Albuquerque (2010), many in vitro plant cultures can synchronously develop bacterial growths during several of their micropropagation phases. This can occur even if the cultures were apparently pure after several sub-cultivations, in general due to the presence of endophytic or fastidious microorganisms. Therefore, the bacterial contaminations that occurred during this study are believed to have evolved from latent endophytic microorganisms or low concentrations of these microorganisms that are present in the $P$. cattleianum tissues that later proliferate in the culture medium.

On the 15th day after the in vitro introduction of the explants, the number of buds $(\mathrm{p}=0.0724)$ and oxidation percentage $(p=0.3804)$ showed no significant effects for the different treatments, with values ranging from 0.14 and 0.57 for buds per explant, and from $17.14 \%$ and $34.29 \%$ for oxidation (Table 2). An assessment on the 45th day of contact with the culture medium, however, showed a significant effect on the bacterial contamination percentages $(\mathrm{p}<0.0001)$, oxidation percentages $(\mathrm{p}=0.0020)$ and in vitro establishment of the explants $(\mathrm{p}=$ 0.0012), as can be seen on Figure 4. 


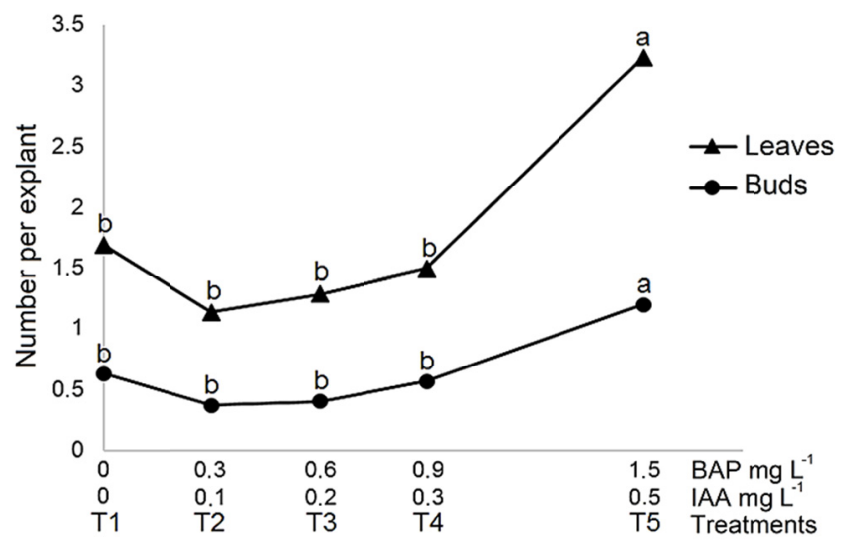

Figure 4. Bacterial contamination percentages, oxidation percentages, and in vitro establishment percentages for Red Araçá (Psidium cattleianum) nodal segments after 45 days of cultivation in an MS culture medium, with different concentrations of BAP and IAA

Note. Averages indicated by the same letter in the same variable do not differ among themselves by the Scott-Knott test at $5 \%$ significance level.

After 45 days in vitro, no significant differences were detected in terms of bacterial contamination percentages, oxidation percentages and establishment rates for treatments T1 thru T4 (up to $0.9 \mathrm{mg} \mathrm{L}^{-1}$ of BAP and $0.3 \mathrm{mg} \mathrm{L}^{-1}$ of IAA). These treatments, however, were quite different from the T5 treatment for all assessed variables. One can also note a tendency for bacterial contamination percentages and oxidation percentages to decrease, and establishment rates to increase with an increase of phytohormone concentrations in the culture medium. The results show that the addition of the highest tested dosage (T5, or $1.5 \mathrm{mg} \mathrm{L}^{-1}$ of BAP and $0.5 \mathrm{mg} \mathrm{L}^{-1}$ of IAA) to the culture medium is the best treatment for the in vitro multiplication of $P$. cattleianum, evidenced by its lowest bacterial contamination percentage $(42.86 \%)$ and oxidation percentage $(31.43 \%)$, as well as the highest percentage of in vitro nodal segments establishment (51.43\%) (Figure 4).

Data gathered by Rodríguez (2013), Souza, Fior, Souza, and Schwarz (2011), and Lattuada (2010) are different than what was observed during this study. Rodríguez (2013) tested different combinations of BAP (between 0 $\mathrm{mg} \mathrm{L}^{-1}$ and $1.5 \mathrm{mg} \mathrm{L}^{-1}$ ) and NAA (between $0 \mathrm{mg} \mathrm{L}^{-1}$ and $0.5 \mathrm{mg} \mathrm{L}^{-1}$ ) with $P$. cattleianum apical segments. As reported by Rodriguez, an increase in the concentration of the above mentioned compounds resulted in negative effects, such as a high mortality rate (average of $70 \%$ ) and an increase in the malformation of the explants. Souza, Fior, Souza, and Schwarz (2011) studied the effects of increasing concentrations of BAP (between $0 \mathrm{mg} \mathrm{L}^{-1}$ and $2 \mathrm{mg} \mathrm{L}^{-1}$ ), determining that higher concentrations of the compound caused an increase in oxidation and a decrease in establishment rates of "guabijuzeiro" (Myrcianthes pungens, Myrtaceae) apical segments. Lattuada (2010) also detected phytotoxic effects during in vitro multiplication of "pitangueira" (Eugenia uniflora, Myrtaceae) nodal segments, which the author related to the high doses of BAP used. This last author determined that the explants' survival rate decreased with increasing concentrations of BAP (between $0 \mathrm{mg} \mathrm{L}^{-1}$ and $0.5 \mathrm{mg}$ $\mathrm{L}^{-1}$ ).

As was the case with bacterial contamination percentages, oxidation percentages, and in vitro establishment percentages, results for the $P$. cattleianum number of buds per explant $(\mathrm{p}=0.0006)$ and number of leaves per explant $(p=0.0052)$ also showed significant variations for the different BAP and IAA treatments (Figure 5).

In essence, increases in BAP and IAA concentrations yielded an increase in number of leaves and number of buds per explant (Figure 5). The highest concentration of BAP and IAA (T5) resulted in the highest explant in vitro development, with 3.23 leaves and 1.20 buds per explant, quite different from the other treatments. 


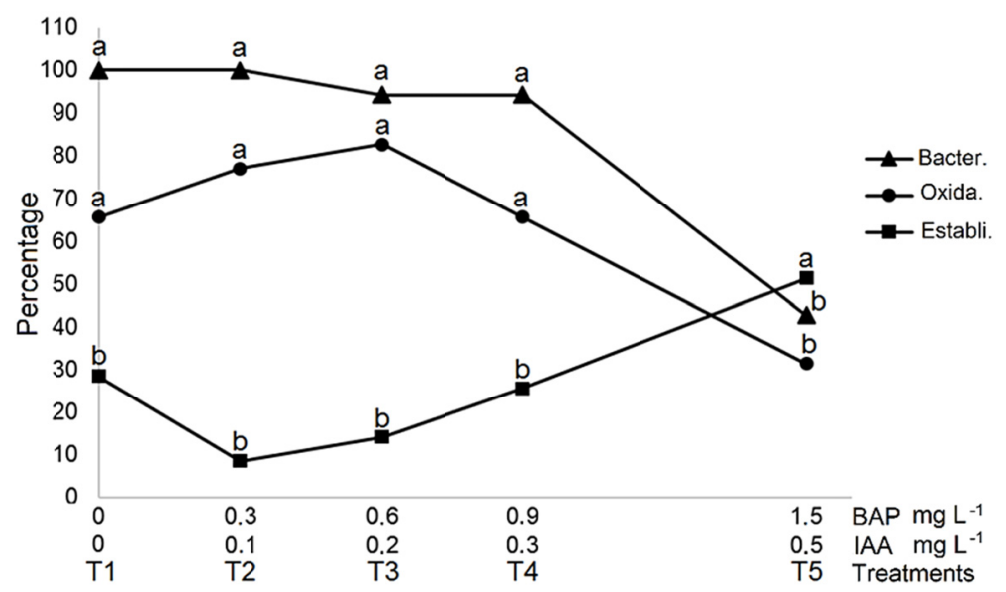

Figure 5. Number of leaves and number of buds per explant for Red Araçá (Psidium cattleianum) nodal segments after 45 days of in vitro cultivation in an MS culture medium, with different concentrations of BAP and IAA

Note. Averages indicated by the same letter in the same variable do not differ among themselves by the Scott-Knott test at $5 \%$.

As reported by Grattapaglia and Machado (1998), and George, Hall, and De Klerk (2008), concentrations of cytokinins and auxins in the culture medium are among the factors that most affect in vitro explant regeneration and multiplication, which are influenced by the concentrations and the types of phytohormones used.

Concentrations of BAP similar to the ones used in this experiment also resulted in positive in vitro responses from other species. In a study with cedar (Cedrela fissilis), Amaral (2006), for example, concluded that a dosage of $5 \mu \mathrm{M}$ of BAP (approximately $1.125 \mathrm{mg} \mathrm{L}^{-1}$ ) yielded the best results in terms of bud production, regardless of the presence or absence of $0.5 \mu \mathrm{M}$ of IAA or $0.5 \mu \mathrm{M}$ of Indolebutyric Acid (IBA). That same concentration of BAP was also efficient for bud growth on "pitangueira" (E. uniflora) explants in the absence of auxins (Souza, Schuch, Donini, \& Ribeiro, 2008).

For myrtaceae explants, however, higher concentrations of phytohormones have proven to be phytotoxic. Rai, Jaiswal, and Jaiswal (2009), for example, have determined that an increase of BAP concentration, up to $1.0 \mathrm{mg}$ $\mathrm{L}^{-1}$, also increases the number of buds during in vitro multiplication of the guava tree (Psidium guajava). When a higher concentration $\left(2 \mathrm{mg} \mathrm{L}^{-1}\right)$ was used, a sharp decrease in the formation of buds was observed. Similarly, Ribeiro, Souza, Donini, and Schuch (2007) determined that a $5 \mu \mathrm{M}$ dosage of BAP in a WPM medium yielded a higher number of leaves and buds per explant of $P$. cattleianum nodal segments than when cytokinin was absent; they also noticed, however, that those same variables decreased when $10 \mu \mathrm{M}$ of BAP was added to the medium.

\subsection{Different Concentrations of Antibiotics in the Culture Medium}

Table 3 shows the results for all assessed variables after the addition of ampicillin to the culture medium. 
Table 3. Bacterial and fungal contamination percentages, oxidation percentages, rooting percentages, number of leaves, and relative growth rate (RGR) for contaminated Psidium cattleianum explants after the 15th and 45th day of in vitro cultivation in an MS medium, with different concentrations of ampicillin

\begin{tabular}{|c|c|c|c|}
\hline \multirow{2}{*}{ Ampicillin $\left(\mathrm{mg} \mathrm{L}^{-1}\right)$} & \multicolumn{3}{|c|}{ Bacterial Contamination (\%) } \\
\hline & $15^{\text {th }}$ day & $45^{\text {th }}$ day & Average \\
\hline 250 & 0.00 & 15.00 & $7.50 \mathrm{a}$ \\
\hline 500 & 0.00 & 0.00 & $0.00 \mathrm{~b}$ \\
\hline Average & $0.00^{\mathrm{ns}^{-}}$ & $7.50^{\mathrm{ns}}$ & \\
\hline \multirow{2}{*}{ Ampicillin $\left(\mathrm{mg} \mathrm{L}^{-1}\right)$} & \multicolumn{3}{|c|}{ Fungal Contamination (\%) } \\
\hline & $15^{\text {th }}$ day & $45^{\text {th }}$ day & Average \\
\hline 250 & 0.00 & 0.00 & $0.00^{\mathrm{ns}}$ \\
\hline 500 & 0.00 & 0.00 & $0.00^{\mathrm{ns}}$ \\
\hline Average & $0.00^{\mathrm{ns}}$ & $0.00^{\mathrm{ns}}$ & \\
\hline \multirow{2}{*}{ Ampicillin $\left(\mathrm{mg} \mathrm{L}^{-1}\right)$} & \multicolumn{3}{|c|}{ Oxidation $(\%)$} \\
\hline & $15^{\text {th }}$ day & $45^{\text {th }}$ day & Average \\
\hline 250 & 0.00 & 10.00 & $5.00 \mathrm{~b}$ \\
\hline 500 & 15.00 & 25.00 & $20.00 \mathrm{a}$ \\
\hline Average & $7.50^{\mathrm{ns}-}$ & $17.50^{\mathrm{ns}}$ & \\
\hline \multirow{2}{*}{ Ampicillin $\left(\mathrm{mg} \mathrm{L}^{-1}\right)$} & \multicolumn{3}{|c|}{ Rooting $(\%)$} \\
\hline & $15^{\text {th }}$ day & $45^{\text {th }}$ day & Average \\
\hline 250 & 0.00 & 10.00 & $5.00^{\mathrm{ns}}$ \\
\hline 500 & 5.00 & 20.00 & $12.50^{\mathrm{ns}}$ \\
\hline Average & $2.50 \mathrm{~b}$ & $15.00 \mathrm{a}$ & \\
\hline \multirow{2}{*}{ Ampicillin $\left(\mathrm{mg} \mathrm{L}^{-1}\right)$} & \multicolumn{3}{|c|}{ Number of Leaves explant $^{-1}$} \\
\hline & $15^{\text {th }}$ day & $45^{\text {th }}$ day & Average \\
\hline 250 & 5.05 & 6.75 & $5.90^{\mathrm{ns}}$ \\
\hline 500 & 4.75 & 5.50 & $5.12^{\mathrm{ns}}$ \\
\hline Average & $4.90^{\mathrm{ns}^{-}}$ & $6.12^{\mathrm{ns}}$ & \\
\hline \multirow{2}{*}{ Ampicillin $\left(\mathrm{mg} \mathrm{L}^{-1}\right)$} & \multicolumn{3}{|c|}{ Relative Growth Rate $\left(\mathrm{mm} \mathrm{mm}^{-1}\right.$ day $^{-1}$ explant $\left.^{-1}\right)$} \\
\hline & $15^{\text {th }}$ day & $45^{\text {th }}$ day & Average \\
\hline 250 & 0.017 & 0.012 & $0.014^{\mathrm{ns}}$ \\
\hline 500 & 0.019 & 0.011 & $0.015^{\mathrm{ns}}$ \\
\hline Average & $0.018^{\mathrm{ns}}$ & $0.011^{\mathrm{ns}}$ & \\
\hline
\end{tabular}

Note. For each variable, recorded values appended by the same letter, lower case within a row and upper case within a column, do not differ statistically from each other according to the Tukey test, within a $5 \%$ significance level. ${ }^{\text {ns }}$ Not significant.

The concentrations of ampicillin added to the medium for the purposes of this study efficiently suppressed contaminations $(p=0.0240)$ and were not phytotoxic to the explants. Throughout the experiment, no bacterial contamination was detected when the medium was treated with $500 \mathrm{mg} \mathrm{L}^{-1}$ of ampicillin, with its contamination percentage being statistically inferior $(p=0.0240)$ to that obtained when treated with $250 \mathrm{mg} \mathrm{L}^{-1}$ of ampicillin (Table 3).

After 45 days of being kept in a medium with $500 \mathrm{mg} \mathrm{L}^{-1}$ of ampicillin, the explants went through a development phase that made them grow in length $\left(\mathrm{RGR}=0.011 \mathrm{~mm} \mathrm{~mm} \mathrm{day}^{-1}\right)$ and generated leaves (5.50 per explant), with $20 \%$ of them experiencing rooting, even though the medium was not specific for that process (Table 3). This was evidence that the cultivation of $P$. cattleianum explants, supposedly contaminated with bacteria, in a medium containing $500 \mathrm{mg} \mathrm{L}^{-1}$ of ampicillin resulted in a culture that was free of microorganism, also making its development feasible.

Pasqual, Dutra, Araújo, and Pereira (2010) reported that, when using culture tissue techniques, contaminated seedlings and explants are generally discarded; that, however, shouldn't always be the case, since there are microorganism controlling techniques that can be used. Pereira, Mattos, and Fortes (2003), for example, 
determined that ampicillin, chloramphenicol, streptomycin, and tetracycline (between $32 \mathrm{mg} \mathrm{L}^{-1}$ and $256 \mathrm{mg} \mathrm{L}^{-1}$ ) efficiently inhibited the growth of endophytic bacteria or contaminants in potato tissue cultures (Solanum tuberosum). Similarly, Leifert et al. (1991) cultivated the Delphinium sp. and also obtained cultures that were free of pathogens and showed in vitro growth increases when adding different antibiotics (gentamicin, streptomycin, carbenicillin, cephalothin, rifampicin and polymyxin) to their MS culture medium.

Besides having been quite effective in decontaminating the Red Araçá in this study, other studies and their results have also attested to the effectiveness of adding ampicillin in the culture medium. Araújo (2012), for example, tested different concentrations ( $100 \mathrm{mg} \mathrm{L}^{-1}, 200 \mathrm{mg} \mathrm{L}^{-1}, 300 \mathrm{mg} \mathrm{L}^{-1}, 400 \mathrm{mg} \mathrm{L}^{-1}, 500 \mathrm{mg} \mathrm{L}^{-1}$ and $600 \mathrm{mg} \mathrm{L}^{-1}$ ) of ampicillin in the culture medium for the in vitro establishment of the "camu-camuzeiro" (Myrciaria dubia, Myrtaceae), which, after 30 days, yielded an establishment rate of $50 \%$ and $0 \%$ bacterial and fungal contaminations. Additionally, Pereira and Fortes (2003) reported that culture mediums with concentrations of up to $1,024 \mathrm{mg} \mathrm{L}^{-1}$ of ampicillin are not phytotoxic to the in vitro cultivation of potatoes (Solanum tuberosum) because it decontaminates the explants and does not prevent their development.

\subsection{Growth Phytohormones during the Morphogenesis of Apical Segments}

Treatments of the full strength MS medium with different concentrations of BAP and IAA phytohormones did not significantly affect oxidation percentages $(p=0.4242)$, rooting percentages $(p=0.3910)$, number of leaves per explant $(\mathrm{p}=0.2537)$ and relative growth rate per explant $(\mathrm{RGR})(\mathrm{p}=0.4679)$ (Table 4). Significant differences were only detected between dates of assessment for the variables rooting percentages $(p=0.0004)$ and number of leaves per explant $(\mathrm{p}=0.0002)$, both being higher on the 40th day of in vitro cultivation (Table 4).

Table 4. Oxidation percentages, rooting percentages, number of leaves and relative growth rates (RGR) for Red Araçá (Psidium cattleianum) apical segments after the 18th and 40th day of in vitro cultivation in an MS medium containing different concentrations of phytohormones

\begin{tabular}{|c|c|c|c|}
\hline \multirow{2}{*}{ Treatment $\left(\mathrm{mg} \mathrm{L}^{-1}\right)$} & \multicolumn{3}{|c|}{ Oxidation (\%) } \\
\hline & $18^{\text {th }}$ day & $40^{\text {th }}$ day & Average \\
\hline (T1) 1.0 de BAP & 6.67 & 13.33 & $10.00^{\mathrm{ns}}$ \\
\hline (T2) 2.0 de BAP & 0.00 & 6.67 & $3.33^{\mathrm{ns}}$ \\
\hline (T3) 2.0 de BAP e 0.5 de IAA & 0.00 & 6.67 & $3.33^{\text {ns }}$ \\
\hline Average & $2.22^{\mathrm{ns}}$ & $8.89^{\text {ns }}$ & \\
\hline \multirow{2}{*}{ Treatment $\left(\mathrm{mg} \mathrm{L}^{-1}\right)$} & \multicolumn{3}{|c|}{ Rooting $(\%)$} \\
\hline & $18^{\text {th }}$ day & $40^{\text {th }}$ day & Average \\
\hline (T1) 1.0 de BAP & 20.00 & 53.33 & $36.67^{\mathrm{ns}}$ \\
\hline (T2) 2.0 de BAP & 0.00 & 66.67 & $33.33^{\text {ns }}$ \\
\hline (T3) 2.0 de BAP e 0.5 de IAA & 6.67 & 33.33 & $20.00^{\mathrm{ns}}$ \\
\hline Average & $8.89 \mathrm{~b}$ & $51.11 \mathrm{a}$ & \\
\hline \multirow{2}{*}{ Treatment $\left(\mathrm{mg} \mathrm{L}^{-1}\right)$} & \multicolumn{3}{|c|}{ Number of Leaves explant ${ }^{-1}$} \\
\hline & $18^{\text {th }}$ day & $40^{\text {th }}$ day & Average \\
\hline (T1) 1.0 de BAP & 4.60 & 5.80 & $5.20^{\text {ns }}$ \\
\hline (T2) 2.0 de BAP & 4.60 & 6.67 & $5.64^{\mathrm{ns}}$ \\
\hline (T3) 2.0 de BAP e 0.5 de IAA & 5.07 & 6.93 & $6.00^{\mathrm{ns}}$ \\
\hline Average & $4.75 \mathrm{~b}$ & $6.47 \mathrm{a}$ & \\
\hline \multirow{2}{*}{ Treatment $\left(\mathrm{mg} \mathrm{L}^{-1}\right)$} & \multicolumn{3}{|c|}{ Relative Growth Rate $\left(\mathrm{mm} \mathrm{mm}^{-1}\right.$ day $^{-1}$ explant $\left.^{-1}\right)$} \\
\hline & $18^{\text {th }}$ day & $40^{\text {th }}$ day & Average \\
\hline (T1) 1.0 de BAP & 0.0156 & 0.0131 & $0.0145^{\mathrm{ns}}$ \\
\hline (T2) 2.0 de BAP & 0.0157 & 0.0124 & $0.0140^{\mathrm{ns}}$ \\
\hline (T3) 2.0 de BAP e 0.5 de IAA & 0.0177 & 0.0152 & $0.0164^{\mathrm{ns}}$ \\
\hline Average & $0.0163^{\mathrm{ns}}$ & $0.0136^{\mathrm{ns}}$ & \\
\hline
\end{tabular}

Note. For each variable, recorded values appended by the same letter, lower case within a row and upper case within a column, do not differ statistically from each other according to the Tukey test, within a $5 \%$ significance level. ${ }^{\text {ns }}$ Not significant. 
The results of experiments performed in this study with respect to Red Araçás in vitro rooting percentage are unprecedented in the existing literature. In vitro cultivated Red Araçá apical segments showed no restrictions as to the rhizogenesis process (Figure 6A), with an average rooting of $51.11 \%$ after the 4 th day (Table 4). The highest rooting percentage, $66.67 \%$, was attained with treatment $\mathrm{T} 2$, even in the presence of high osmotic pressure and a high concentration of cytokinin $\left(2 \mathrm{mg} \mathrm{L}^{-1}\right.$ of BAP) in the medium (full strength MS) (Table 4). On the 18th day in vitro, complete (rooted) plants had already been obtained (Figure 6A); and, between the 40th and the 60th day, a root system was already in place, with secondary root growths (Figure 6E). This rooting data is entirely relevant for research efforts involving $P$. cattleianum micropropagation, especially considering that one of the greatest difficulties mentioned in the existing literature about micropropagation protocols for species of trees, including the Myrtaceae, is the inefficiency of in vitro formation of adventitious roots (George, Hall, \& De Klerk, 2008; Grattapaglia \& Machado, 1998).

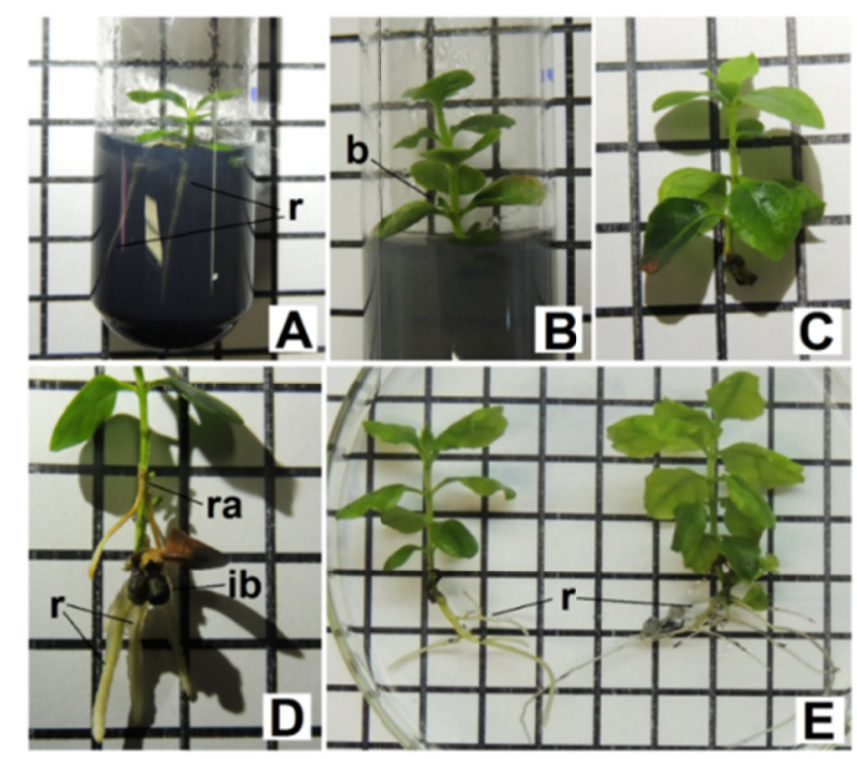

Figure 6. In vitro micropropagated Psidium cattleianum apical segments in MS medium containing BAP and IAA

Note. A, explant containing basal roots (r) after 18 days in vitro; B, explant with over two centimeters in length and lateral bud development (b) after 40 days in vitro; $\mathrm{C}$, general appearance of non-rooted buds attained after 40 days; D, explant showing basal roots (r), adventitious roots at the stem's internodes (ra) and basal intumescence (ib); E, general appearance of fully formed plants attained after 60 days in vitro, with a root system and secondary roots. Squares were dimensioned at $1 \mathrm{~cm}$ by $1 \mathrm{~cm}$.

Souza (2010), for example, reported an average rooting of only 3.5\% for "guabijuzeiro" (Myrcianthes pungens) explants, when testing different concentrations $\left(0.2 \mathrm{mg} \mathrm{L}^{-1} ; 0.4 \mathrm{mg} \mathrm{L}^{-1}\right.$ and $\left.0.6 \mathrm{mg} \mathrm{L}^{-1}\right)$ of NAA and IBA auxins in a WPM medium. According to the author, a high percentage of callogenesis at the base of the explants was one of the factors that contributed to the resulting low rhizogenesis. Similarly, Lattuada (2010) tested different dosages of NAA (between $0 \mathrm{mg} \mathrm{L}^{-1}$ and $0.5 \mathrm{mg} \mathrm{L}^{-1}$ ) in a WPM medium and assessed the in vitro formation of roots in "pitangueira" (Eugenia uniflora) explants, recording a maximum rooting percentage of approximately $10 \%$ when using an NAA concentration of $0.24 \mathrm{mg} \mathrm{L}^{-1}$.

\subsection{Pre-Acclimatization of Micropropagated Red Araçá Plants}

On the 20th and 42nd days, no significant difference in survival percentages $(p=0.5571)$ was observed for the types of substrate used in the pre-acclimatization phase (Figure 7). Though not significant, it was determined that substrate S1 (Maxfértil®, a commercial substrate) yielded higher survival rates for both the 20th and the 42nd days, with $81.82 \%$ and $72.73 \%$, respectively (Figure 7 ). It was also noticeable that substrate combinations can influence, or not, the acclimatization of micropropagated plants, depending on the species being studied and several other factors, such as phytohormonal variations, relative humidity, and luminous intensity (Pospíšilová, Synková, Haisel, \& Semorádová, 2007). 


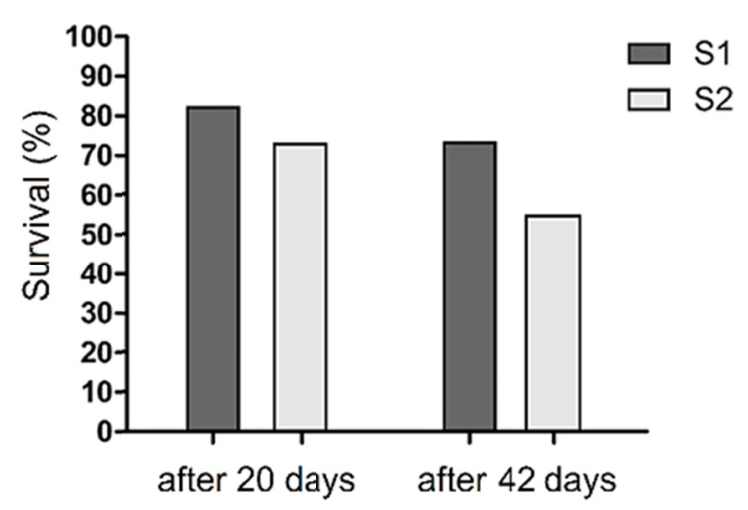

Figure 7. Survival percentage of micropropagated Psidium cattleianum plants in different substrates, during pre-acclimatization

Note. S1, commercial substrate from Maxfértil ${ }^{\circledR}$; S2, commercial substrate from Maxfértil ${ }^{\circledR}$ mixed with sterilized washed sand, in a 1:1 mass proportion. Not significant by Chi-square test at $5 \%$ significance level.

Similar survival percentages were observed during the acclimatization of other micropropagated myrtaceae. Sospedra et al. (2003), for example, recorded an average survival rate of $75 \%$ for micropropagated "araçá-rasteiro" (Psidium salutare) plants. By the same token, Nascimento et al. (2008) reported an average survival rate of $77 \%$ for micropropagated "uvaieira" (Eugenia pyriformis) plants.

Up to the time of this study, there was absolutely no data related to acclimatization survival percentages of micropropagated P. cattleianum plants. The unprecedented data gathered here is evidence that transplantation of this species can indeed be done with the substrates used in this experiment, coupled with the use of a nebulizer chamber, or comparable equipment that can sustain high relative humidity (between $88 \%$ and $95 \%$ ).

During the experiment, all surviving plants were soft and green, and developed new leaves within two to three weeks after being transplanted into the substrate (Figure 8F), while the non-surviving plants showed water stress, followed by foliar senescence and abscission. Among other factors, the water stress is believed to have been caused by stomas malformation or dysfunction (Costa, Pasqual, Scherwinski, \& Castro, 2009), a thin or inexistent layer of protective wax, or even by an in vitro developed vascular system that was disconnected or less efficient (George, Hall, \& De Klerk, 2008).

After a period in the nebulizer chamber, the pre-acclimatized plants were transferred to field conditions and monitored. Those plants formed well developed leaves and showed normal stem development, whose appearance after 180 days in the acclimatization substrate can be seen in Figure 8G.

This study made it possible to develop a complete protocol for the micropropagation of the Red Araçá (Psidium cattleianum) from seedlings obtained by in vitro germination, as can be seen in Figure 8. Results ascertained that approximately $95 \%$ of the introduced explants were actually established in vitro and showed contamination levels that were almost null, regardless of the type of explant used. The experiments also determined that explants can multiply in different concentrations of cytokinins and auxins, exhibiting in vitro rhizogenic capacity with low restrictiveness, which translated to approximately $70 \%$ rooting. These factors made it possible for the seedlings to completely regenerate from nodal and apical segments. Additionally, unprecedented results were obtained during pre-acclimatization, with a survival rate of approximately $80 \%$. 

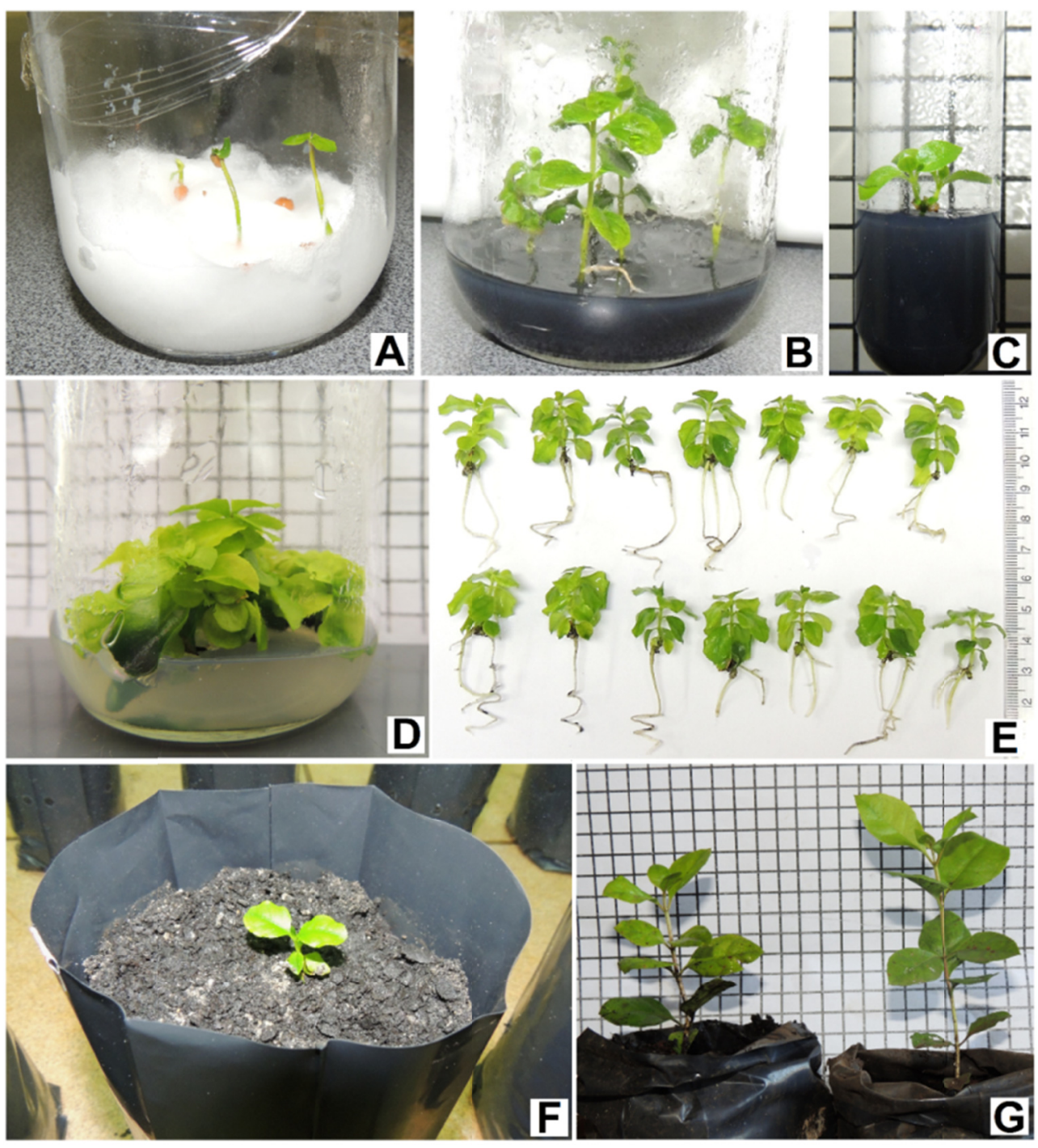

Figure 8. Red Araçá (Psidium cattleianum) in vitro propagation phases

Note. A, seedlings obtained from in vitro germination in hydrophilic cotton; B, plants elongated in MS medium; $\mathrm{C}$, internode with bud growths in a medium containing ampicillin; $\mathrm{D}$, bud multiplication in a medium containing BAP and IAA; E, rooted plants; F, plant in the process of pre-acclimatization, after 20 days in the substrate; G, acclimatized plants, after 180 days in the substrate. Squares were dimensioned at $1 \mathrm{~cm}$ by $1 \mathrm{~cm}$. Epagri's Plant Tissue Cultures Laboratory in the City of Caçador.

\section{Conclusions}

When taking into account all the conditions for the development of the experiments in this study, the main conclusions were as follows:

$>\quad$ In vitro introduction of Red Araçá from seedlings obtained through germination is efficient, regardless of the presence or absence of paracotyledons and radicle roots in the explants;

> Even after 90 days of in vitro introduction, Red Araçá explants, though showing no signs of contaminants, can develop bacterial contaminations in the multiplication phase, possibly due to the presence of endophytic or fastidious microorganisms;

$>$ Increasing concentrations of BAP and IAA in the MS medium enhance the development of nodal shoot segments;

> An MS medium with $500 \mathrm{mg} \mathrm{L}^{-1}$ of ampicillin can be used to decontaminate Red Araçá apical segments without phytotoxic effects and maintaining the explants' in vitro development and rooting rates; 
$>\quad$ Even in mediums containing high osmotic pressure and cytokinins, in vitro Red Araçá apical segments still develop adventitious roots;

$>\quad$ It is possible to obtain complete (rooted) in vitro plants from apical segments in a full strength MS medium treated with different combinations of BAP and IAA;

$>\quad$ Pre-acclimatization of in vitro multiplied and rooted Red Araçá plants is efficient when using a commercial substrate, or a combination of commercial substrate and sand;

$>$ In essence, it was indeed possible to develop a complete protocol for the micropropagation of the Red Araçá (establishment, multiplication, rooting, and acclimatization) from seedlings obtained by in vitro germination, just as it could be done for other Myrtaceae.

\section{Acknowledgements}

The authors thank Dr. Marcus Vinicius Kvitschal and Dr. Maraisa Crestani Hawerroth of Epagri Caçador/SC by the granting the nebulizer chamber and assistance in pre-acclimatization experiment.

\section{References}

Amaral, V. F. M. (2006). Multiplicação in vitro de Cedrela fissilis Vell (Unpublished dissertation in partial fulfillment of the requirements for the degree of Master in Forest Engineering, Universidade Federal de Santa Maria, Santa Maria, RS).

Araújo, M. C. R. (2012). Desinfestação e estabelecimento in vitro de segmentos caulinares de camu-camuzeiro (Unpublished dissertation in partial fulfillment of the requirements for the degree of Master in Agronomy, Universidade Federal de Roraima, Boa vista, RR).

Baker, H. G., Baker, I., \& Hodges, S. A. (1998). Sugar composition of nectars and fruits consumed by birds and bats in the tropics and subtropics. Biotropica, 30, 559-586. https://doi.org/10.1111/j.1744-7429.1998. tb00097.x

Briggs, G. E., Kid, F., \& West, C. (1920). A quantitative analysis of plant growth. Part 1. Annals of Applied Biology, 7, 103-123. https://doi.org/10.1111/j.1744-7348.1920.tb05107.x

Camara, T. R., Willadino, L., \& Albuquerque, C. C. (2010). Microrganismos assintomáticos do cultivo in vitro: natureza e riscos para o cultivo de plantas. In J. E. Scherwinski-Pereira (Ed.), Contaminação microbianas na cultura de células, tecidos e órgãos de plantas (pp. 221-260). Brasília, DF: Embrapa Informação Tecnológica.

Cisneiro, R. A., Matos, V. P., Lemos, M. A., Reis, O. V., \& Queiroz, R. M. (2003). Physiological quality of seeds of Psidium guineense Swartz during storage. Revista Brasileira de Engenharia Agrícola e Ambiental, 7(3), 513-518. https://doi.org/10.1590/S1415-43662003000300018

Costa, F. H. S., Pasqual, M. P., Scherwinski, J. E., \& Castro, E. M. (2009). Anatomical and physiological modifications of micropropagated 'Caipira' banana plants under natural light. Sci. Agr., 66(3), 323-330. https://doi.org/10.1590/S0103-90162009000300007

Da Silva, A., Gualtieri, S. C. J., Paula, R. C., \& Paoli, A. A. S. (2013). Biometria, morfologia de frutos, sementes, plântulas e plantas jovem de Psidium cattleianum Sabine (pp. 1-1). Sétimo Seminário de Iniciação Científica do Instituto Florestal, São Paulo. São Paulo: Instituto Florestal.

Embrapa. (2006). Espécies nativas recomendadas para recuperação ambiental no estado do Paraná, em solos não degradados. Antonio Aparecido Carpanezzi, Odete T. Bertol Carpanezzi. Colombo: Embrapa Florestas.

Falkenberg, D. B., \& Simões, T. (2011). Espécies de interesse apícola e sua fenologia de floração. In L. Coradin, A. Siminski, \& A. Reis (Eds.), Espécies nativas da flora brasileira de valor econômico atual ou potencial: Plantas para o futuro-região Sul (p. 934). Brasília: MMA.

Franzon, R. C., Campos, L. Z. O., Proença, C. E. B., \& Sousa-Silva, J. C. (2009). Araçás do gênero Psidium: principais espécies, ocorrência, descrição e usos (p. 48). Planaltina, DF: Embrapa Cerrados.

Freire, C. G. (2013). Micropropagação de espécies nativas frutíferas do sul brasileiro (Unpublished monograph in partial fulfillment of the requirements for the degree of Bacharelor in Biological Sciences, Universidade do Alto Vale do Rio do Peixe, Caçador, SC).

Freire, C. G., Gardin, J. P. P., Baratto, C. M., \& Vieira, R. L. (2017). Different methods for overcoming integumental dormancy during in vitro germination of red Araza seeds. Journal of Agricultural Science, 9(1), 174-183. https://doi.org/10.5539/jas.v9n1p174 
Freire, C. G., Oliveira, L. P. de, \& Vieira, R. L. (2014). Tratamento fungicida e diferentes assepsias na introdução in vitro de araçazeiro-vermelho (Psidium cattleianum) (pp. 14-14). X Simpósio Florestal Catarinense, 2014, Curitibanos, SC. Anais do X Simpósio Florestal Catarinense Florestas Produtivas, Cenários e Perspectivas.

Galho, A. S., Lopes, N. F., Bacarin, M. A., \& Lima, M. G. S. (2007). Chemical composition and growth respiration in Psidium cattleyanum Sabine fruits during the development cycle. Rev. Bras. Frutic., 29(1), 61-66. https://doi.org/10.1590/S0100-29452007000100014

George, E. F., Hall, M. A., \& De Klerk, G. (Eds.). (2008). Plant propagation of tissue culture. The background (3rd ed., Vol. 1, p. 502). Springer.

Golle, D. P., Reiniger, L. R. S., Belle, R. A., \& Curti, A. R. (2013). Superficial disinfestation of isolated explants from semi-hardwood and herbaceous branches of Eugenia involucrata DC. (Myrtaceae). Cerne, 19(1), 77-82. https://doi.org/10.1590/S0104-77602013000100010

Grattapaglia, D., \& Machado, M. A. (1998). Micropropagação. In A. C. Torres, L. S. Caldas, \& J. A. Buso (Eds.), Tissue culture and genetic transformation of plants (Vol. 1, pp. 183-260). Brasília: SPI/Embrapa-CNPH.

Gressler, E., Pizo, M. A., \& Morellato, P. C. (2006). Pollination and seed dispersal of Brazilian Myrtaceae. Revista Brasil. Bot., 29(4), 509-530. https://doi.org/10.1590/S0100-84042006000400002

Hartmann, H. T. M., Kester, D. E., \& Davies Junior, F. T. (1990). Plant propagation: Principles and practices (5th ed., p. 647). Englewood Cliffs: Prentice Hall.

IEA (Instituto de Economia Agrícola). (2017). Retrieved September 10, 2017, from http://www.iea.agricultura. sp.gov.br/out/index.php

Kinupp, V. F. (2011). Native food species from southern Brazil. In L. Coradin, A. Siminski, \& A. Reis (Eds.), Native species of flora of current or potential economic value: Plans for the future (p. 934). Brasília: MMA.

Kuhlmann, M. (1975). Adendo alimentar dos bugios (Vol. 9, pp. 57-62). Silvicultura de São Paulo.

Lattuada, D. S. (2010). Micropropagação e miniestaquia de pitangueira (Eugenia uniflora) (Unpublished dissertation in partial fulfillment of the requirements for the degree of Master in Phytotechnic with emphasis on horticulture, Universidade Federal do Rio Grande do Sul, UFRGS, Porto Alegre, RS).

Leifert, C., Camotta, H., Wright, S. M., Waites, B., Cheyne, V. A., \& Waites, W. M. (1991). Elimination of Lactobacillus plantarum, Corynebacterium spp., Staphylococcus saprophyticus and Pseudomonas paucimobilis from micropropagated Hemerocallis, Choisya and Delphinium cultures using antibiotics. Journal of Applied Bacteriology, 71(4), 307-330. https://doi.org/10.1111/j.1365-2672.1991.tb03795.x

Liu, X., \& Yang, G. (2011). Clonal propagation of guava (Psidium guajava L) on nodal explants of mature elite cultivar. International Journal of Plant Biology, 2(1), 2. https://doi.org/10.4081/pb.2011.e2

Lorenzi, H. (2008). Árvores brasileiras: Manual de identificação e cultivo de plantas arbóreas do Brasil (Vol. 1, No. 5). Nova Odessa, São Paulo: Instituto Plantarum.

Marin, R., Apel, M. A., Limberger, R. P., Raseira, M. C. B., Pereira, J. F. M., Zuanazzi, J. A. S., \& Henriques, A. T. (2008). Volatile components and antioxidant activity from some myrtaceous fruits cultivated in southern Brasil. Latin American Journal of Pharmacy, 27(2), 172-177.

Medina, A. L., Haas, L. I. R., Chaves, F. C., Salvador, M., Zambiazi, R. C., Silva, W. P., ... Rombald, I. C. V. (2011). Araçá (Psidium cattleianum Sabine) fruit extracts with antioxidant and antimicrobial activities and antiproliferative effect on human cancer cells. Food Chemistry, 128, 916-922. https://doi.org/10.1016/ j.foodchem.2011.03.119

Murashige, T. (1974). Plant propagation through tissue cultures. Annual Review of Plant Physiology, 25, $135-166$. https://doi.org/10.1146/annurev.pp.25.060174.001031

Murashige, T., \& Skoog, F. (1962). A revised médium for rapid growth and bioassay with tobacco tissue cultures. Physiologia Plantarum, 15, 473-497. https://doi.org/10.1111/j.1399-3054.1962.tb08052.x

Myers, N., Mittermeier, R. A., Mittermeier, C. G., Fonseca, G. A. B., \& Kent, J. (2000). Biodiversity hotspots for conservation priorities. Nature, 403, 853-858. https://doi.org/10.1038/35002501

Nascimento, A. C. (2006). Micropropagação de uvaieira (Eugenia pyriformis Cambess) (Unpublished dissertation in partial fulfillment of the requirements for the degree of Master in Agronomy with emphasis on Plant Physiology, Universidade Federal de Lavras, Lavras, MG). 
Nascimento, A. C., Paiva, R., Abbade, L. C., Vargas, D. P., \& Soares, F. P. (2008). Micropropagation of Eugenia pyriformis Cambess: effects of BA and IBA. Revista Verde, 3(2), 20-26.

Paim, A. F. (2011). Contribuições para a micropropagação de Eugenia involucrata DC. e Handroanthus chrysotrichus (Mart. ex DC) Mattos (Unpublished dissertation in partial fulfillment of the requirements for the degree of Master in Plant Engineering with emphasis on Silviculture, Universidade Federal de Santa Maria, Santa Maria, RS).

Pasqual, M., Chagas, E. A., Soares, J. D. R., \& Rodrigues, F. A. (2012). Tissue culture techniques for native Amazonian fruit trees. In A. Leva \& L. M. R. Rinaldi (Eds.), Recent advances in plant in vitro culture (p. 220). Intech. https://doi.org/10.5772/52760

Pasqual, M., Dutra, L. F., Araújo, A. G., \& Pereira, A. R. (2010). Prevenção de contaminações microbianas na cultura de células, tecidos e órgãos de plantas. In J. E. Scherwinski-Pereira (Ed.), Contaminações microbianas na cultura de células, tecidos e órgãos de plantas (pp. 61-162). Brasília, DF: Embrapa Informação Tecnológica.

Pasqual, M., Hoffmann, A., \& Ramos, J. D. (1998). Cultura de tecidos vegetais: Tecnologia e aplicações-Introdução: Fundamentos básicos. Lavras: UFLA/FAEPE.

Pereira, J. E. S., \& Fortes, G. R. L. (2003). Antibiotics toxicity on the in vitro potato cultivation in semi-solid and liquid media. Pesquisa Agropecuária Brasileira, 38(11), 1273-1279. https://doi.org/10.1590/S0100-204X2 003001100004

Pereira, J. E. S., Mattos, M. L. T., \& Fortes, G. R. L. (2003). Identification and antibiotic control of endophytic bacteria contaminants in micropropagated potato explants. Pesquisa Agropecuária Brasileira, 38(7), 827-834. https://doi.org/10.1590/S0100-204X2003000700006

Pospíšilová, J., Synková, H., Haisel, D., \& Semorádová, Š. (2007). Acclimation of plantlets to ex vitro conditions: Effects of air humidity, irradiance, $\mathrm{CO}_{2}$ concentration and abscisic acid. Acta Hortic., 748, 29-38. https://doi.org/10.17660/ActaHortic.2007.748.2

Rai, M. K., Jaiswal, V. S., \& Jaiswal, U. (2009). Shoot multiplication and plant regeneration of guava (Psidium guajava L.) from nodal explants of in vitro raised plantets. J. Fruit Ornam. Plant Res., 17(1), 29-38.

Raseira, M. C. B., Antunes, L. E. C., Trevisan, R., \& Goncalves, E. D. (2004). Espécies frutiferas nativas do sul do Brasil (p. 122). Pelotas: Embrapa Clima Temperado.

RBMA (Reserva Da Biosfera Da Mata Atlântica). (2017). Anuário da Mata Atlântica: Aspectos gerais da biodiversidade. Retrieved April 17, 2017, from http://www.rbma.org.br/anuario/mata_04_aspectos.asp

Ribeiro, M. F. (2007). Multiplicação e enraizamento in vitro de araçazeiro (Psidium cattleyanum Sabine) cultivar Irapuã (p. 41, Unpublished monograph in partial fulfillment of the requirements for the degree of Bacharelor in Biological Sciences with emphasis on Environment, Universidade Federal de Pelotas, Pelotas, RS).

Ribeiro, M. F., Souza, J. A., Donini, L. P., \& Schuch, M. W. (2007). Tipo de luz e concentração de BAP na multiplicação in vitro de araçazeiro (Psidium cattleyanum Sabine) cultivar Irapuã. XVI Congresso de Iniciação Científica, Pelotas, RS: UFPel.

Rodríguez, E. A. G. (2013). Contribuições à propagação de araçazeiro (Psidium cattleianum Sab.) $e$ grumixameira (Eugenia brasiliensis Lam.) (Unpublished dissertation in partial fulfillment of the requirements for the degree of Master in Plant Science with emphasis on horticulture, Universidade Federal do Rio Grande do Sul, Porto Alegre, RS).

Scherwinski-Pereira, J. E. (2010). Contaminações microbianas na cultura de células, tecidos e órgãos de plantas (p. 446). Brasília, DF: Embrapa Informação Tecnológica.

Scherwinski-Pereira, J. E., \& Costa, F. H. S. (2010). Estratégias de seleção e uso de substâncias químicas antimicrobianas para o controle de contaminantes na cultura de tecidos de plantas. In J. E. Scherwinski-Pereira (Ed.), Contaminações microbianas na cultura de células, tecidos e órgãos de plantas (pp. 261-292). Brasília, DF: Embrapa Informação Tecnológica.

Silva, F. De A. S. E., \& Azevedo, C. A. V. de. (2009). Principal Components Analysis in the Software Assistat-Statistical Attendance. World Congress on Computers in Agriculture, 7, Reno-NV-USA: American Society of Agricultural and Biological Engineers.

Silva, N. A., Rodrigues, E., Mercadante, A. Z., \& De Rosso, V. V. (2014). Phenolic compounds and carotenoids 
from four fruits native from the Brazilian Atlantic Forest. Journal of Agricultural and Food Chemistry, 62, 5072-5084. https://doi.org/10.1021/jf501211p

Sospedra, R. S., López, M. G., Cruz, L. J., López, G. G., \& Quiñones, E. G. (2003). Micropropagación de Psidium salutare (Myrtaceae). Rev. Jard. Bot. Nac., 24(1-2), 245-250.

Souza, J. A. de, Schuch, M. W., Donini, L. P., \& Ribeiro, M. de F. (2008). Types and concentrations of cytokinin on in vitro multiplication of 'pitangueira'. Ciência Rural, 38(7), 2046-2048. https://doi.org/10.1590/ S0103-84782008000700040

Souza, J. A., Schuch, M. W., \& Silva, L. C. (2006). Effect of the branch type and light regimen provided to the donors-plant in the in vitro establishment of araçazeiro cv. Irapuã. Ciência Rural, 36(6), 1920-1922. https://doi.org/10.1590/S0103-84782006000600041

Souza, J. A., Schuch, M. W., Silva, L. C., Ferri, J., \& Soares, G. C. (2007). Solidificante no meio de cultura e tamanho do explante no estabelecimento da propagação in vitro de pitangueira (Eugenia uniflora L.). $R$. Bras. Agrociência, 13(1), 115-118.

Souza, L. S. (2010). Caracterização de frutos e propagação vegetativa de guabijuzeiro (Myrcianthes pungens (O. Berg) D. Legrand) (Unpublished dissertation in partial fulfillment of the requirements for the degree of Master in Phytotechnic with emphasis on horticulture, Universidade Federal do Rio Grande do Sul, UFRGS, Porto Alegre, RS).

Souza, L. S., Fior, C. S., Souza, P. V. D., \& Schwarz, S. F. (2011). Disinfestation of seeds and in vitro multiplication of guabijuzeiro from apical segments juveniles (Myrcianthes pungens O. Berg) D. Legrand. Revista Brasileira de Fruticultura, 33(3), 691-697. https://doi.org/10.1590/S0100-29452011005000081

Tng, D. Y. P., Goosem, M. W., Paz, C. P., Preece, N. D., Goosem, S., Fensham, R. J., \& Laurance, S. G. W. (2015). Characteristics of the Psidium cattleianum invasion of secondary rainforests. Austral Ecology, 41(4), 344-354. https://doi.org/10.1111/aec.12319

Vibrans, A. C. (2013). Floresta ombrófila mista. Inventário florístico florestal de Santa Catarina (Vol. 3, p. 440). Blumenau, Edifurb.

\section{Copyrights}

Copyright for this article is retained by the author(s), with first publication rights granted to the journal.

This is an open-access article distributed under the terms and conditions of the Creative Commons Attribution license (http://creativecommons.org/licenses/by/4.0/). 